\title{
DE ISLANDSKE MUSEERS PLACERING I KULTURDEBATTEN
}

\author{
Ragnheiður H. Pórarinsdóttir
}

Udviklingen af museer i Island hanger noje sammen med landets kamp for selvstendighed. 1800-tallets national-romantiske bevagelse og dens sogen efter folkelig identitet havde en afgørende rolle. Men i Island er den nationale selvfolelse forst og fremst knyttet til sagaerne. Traditionelt har nordisk filologi og norron litteratur derfor den største, faglige betydning, og udviklingen indenfor anden kulturhistorisk forskning tranges i baggrunden til fordel for de skriftlige kilder. "Ordets magt» er stor, og det er svort at få anerkendt typiske museumsdiscipliner som arkณologi. Skal man forstå museumsudviklingen $i$ Island må man derfor se på den islandske videnskabshistorie forst.

Museerne har en samfundsmæssig rolle som institutioner der skal tjene samfundet og dets udvikling. Deres opgave er at indsamle, registrere, bevare, forske og formidle oplysninger om menneskerne, deres miljø, samfund og historie. Denne femdelte opgave har de islandske museer meget forskellige forudsætninger for at klare. Spørgsmålet om økonomiske ressourcer og museernes ringe størrelse er en vigtig grund til deres manglende formåen. Men der findes en anden forklaring, som har at gøre med hvor museernes befinder sig i deres opbygning og udvikling.

Museerne på Island har deres rødder i 1800-tallets national-romantiske bevægelse og dens søgen efter folkelig identitet, på lignende måde som i de andre nordiske lande. Nationalmuseet, landets ældste museum, blev grundlagt i 1863, på et tidspunkt da selvstændighedskampen mod
Danmark stod på sit højeste, og nødvendigheden for at understrege islendingenes egenverdi var påkrævet. Islandsk selvstændighedskamp gik sin gang med en ny grundlov i 1874, der understregede landets status som en del af det danske kongerige, hjemmestyre i 1904 og personalunion i 1918. I al den tid kom der ingen nye museer, nationen stod sammen og Nationalmuseet kunne nemt klare kravet om at have folkekulturen og identiteten under kontrol. Næste gang det nationale blev sat på prøve, og behovet for en stærk selvfølelse dukkede op igen, var under anden verdenskrig, da den moderne tidsalder kom over islændingene som en spand koldt vand. Næsten fra dag til dag blev det gamle, statiske bonde- og fiskersamfund forvandlet til et moderne og dynamisk industri- og bysamfund. Med et voksende bysamfund, hvor folk i stor stil forlod den 
gamle hjemegn og flyttede til byen, blev det ikke kun nødvendigt med en national identitet. De som flyttede til byerne måtte også finde deres egenværdi og vedligeholde deres rødder i det lokale. En anden ting var at landet under krigen blev besat, først af englænderne, senere af amerikanerne, og det viste, hvor skrøbelig den nyvundne selvstændighed var, og hvor lidt der skulle til for at miste den igen. Med landet besat og fuldt af fremmede soldater blev det nødvendigt at understrege det særegne ved den islandske kultur. På denne tid, lidt efter 1940, dukkede de første lokalhistoriske museer op. F.eks. blev Østlandets lokalhistoriske museum, Minjasafn Austurlands, grundlagt i 1942 som et af de ældste. Akkurat på Øst-Island holdt store allierede tropper til. Man kan spørge sig om det er tilfældigt eller ikke. Godt nok befandt den største del af besættelsesmagten sig i Reykjavík, men hovedstaden Reykjavík havde så travlt med at vokse at den ikke havde tid til at tænke på sin fortid og identitet før i 1950 'erne. Reykjavík bymuseum, som er landets næststørste museum i dag, blev ikke grundlagt før i 1957. De sidste tredive år er det gået stærkt med oprettelsen af nye museer, og der stiftes lokale museer overalt. Museernes udvikling kan deles op i tre faser:

I den forste fase har man entusiasterne, som samler på genstande og oplysninger omkring livet i hjemegnen og stabler samlingerne på benene. De har et stort kendskab til deres lokalsamfund eller fag, og en brændende interesse for at bevare dets historie for eftertiden. De ser på det som deres opgave at samle så meget som muligt. Siden skal tingene bevares og registreres så godt som det nu lader sig gøre. Udstillinger laves efter som pladsen tillader. De arbejder næsten altid gratis, og får meget sjældent noget ud af arbejdet økonomisk, i hvert fald indtil de har opnået anerkendelse hos dem som bevilger pengene. Uden disse menneskers uvurderlige indsats ville der aldrig opstå en samling eller et museum.

I den anden fase kommer de lokale museer, hvor den første generation af uddannede museumsfolk leder arbejdet. For omtrent tyve år siden var det stort set kun Nationalmuseet, som havde uddannede fagfolk. Men for 10-15 år siden skete der en forandring. Da fremkom der et betydeligt antal kanditater, som havde studeret museumsfag (etnologi, arkeologi, folkloristik) i udlandet. Denne nye generation er så småt ved at overtage stillinger ved de største lokale museer, og meget tit er der kun én person ansatt. Denne type museumfolk ser ikke på det som deres hovedopgave at samle på genstande, men prøver hellere at løse andre sider af museumsarbejdet, f.eks. bevaring, registrering og formidling gennem udstillinger og i nogen grad forskning.

I den tredje fase kommer så de store museer med mange ansatte, hvor man prøver at varetage alle museets opgaver. På disse museer foregår der grundforskning og formidling udover gennem udstillinger, f.eks. ved publicering af forskningsresultater o.l. På Island findes der kun to store museer, Nationalmuseet og bymuseet i Reykjavík, selv om et par af de største lokalmuseer er lige på vippen til at komme på dette sidste trin i udviklingen.

\section{MAGT ELLER MAGTESLØSHED?}

Når det er nogenlunde bragt på det rene, hvilken rolle museerne spiller i samfundet, opstår spørgsmålet om museer kan siges at have nogen reel magt. Hvis det viser sig at være tilfældet, hvordan så definere denne magt? 
Ved nærmere eftertanke viser det sig, at der i hvert fald findes to former for magt, museerne kan have: På den ene side kan de have en faglig magt, dvs. museerne og deres videnskabelige personale har en vis autoritet inden for forskningsmiljøet. Denne form for magt medfører oftest, at vedkommende automatisk nyder respekt ude i samfundet. Et eksempel på en negativ side af denne faglige magt er det, når museerne, som forskningsinstitutioner, har en bestemt ideologi og opretholder denne ved at vise træghed til at lade nye ideer og nye indfaldsvinkler komme til i forskningen. Disse nye ideer kunne medføre et andet syn på forskningsmaterialet og føre til nye resultater, hvilket selvfølgelig kunne resultere $i$, at man blev nødt til at revurdere det anerkendte billede af fortiden. Forskning, som bygger på nye indfaldsvinkler, behøver ikke nødvendigvis at føre til de rigtige resultater og kan godt vise sig at bygge på forkerte forudsætninger, men den kan også bidrage til at kaste et helt nyt lys over kulturhistorien. Udelukkende ved ikke at give muligheden for at se tingene i et nyt lys, med deres modstand mod et nyt forskningssyn, bruger museerne deres faglige magt på en negativ måde.

På den anden side kan museerne have en direkte samfundspolitisk magt, dvs. de spiller en bestemt rolle i det lokale samfund, hvor museerne kan påvirke politiske beslutninger med direkte følger for befolkningen. Med andre ord er de en del af en beslutningsproces, når de politiske beslutninger tages. Et eksempel på den samfundspolitiske magt, museerne kan udøve, er deres rolle som skabere af holdninger hos folk. Museerne kan $\mathrm{f}$. eks. have en lovmæsig ret eller pligt til at komme med en udtalelse inden nogle politiske instanser tager en beslutning, som kan påvirke miljøet, f.eks. bevaring af kulturminder, kulturlandskab eller lignende. I de tilfælder har museerne en direkte samfundspolitisk magt. Museernes magt eller magtesløshed genspejles i, hvorvidt deres protest vinder gehør hos myndighederne, når de viser modstand mod politiske beslutninger, f.eks. vedrørende nedrivning af huse. Disse to former for magt er nært knyttet til hinanden, fordi af en faglig magt følger tit en samfundsmæssig magt. En museumsperson, som respekteres for sin faglige autoritet, har lettere ved at påvirke politikere til at tage den rigtige politiske beslutning, f.eks. med hensyn til bevaring af kulturminder, end den fagligt svage, som ingen tager særlig alvorligt.

Det er en kendsgerning, at med magt følger modstand, eller måske rettere sagt, en form for konservatisme. Den, som har magt, vil holde status quo, noget der tit fører til modstand mod forandringer. Museerne kan bruge deres magt til at holde folk med et andet forskningssyn eller andre ideer væk fra mulighederne for at forske eller tie stille med resultaterne af deres forskning. Nye tanker og nye ideer kan derfor få vanskeligt ved at komme igennem og vinde terræn. På Island er der ikke tale om en bevist brug af den slags magt, hvis museerne ikke lader forskere med nye ideer komme til. Deres ressourcemangel og deraf følgende magtesløshed fører let til stagnation og mangel på initiativ inden for museernes forskning.

\section{MUSEERNE OG DEN ISLANDSKE SELVFØLELSE}

I det 19. århundrede opstod der en stærk nationalfølelse på Island. Dengang var landet en del af det danske rige. De natio- 
42 nale ideer fik folk til at tro at nationen ville have det meget bedre som en selvstændig stat, fri og uafhængig af Danmark. For at rettfærdiggøre den idé fandt man på nogle argumenter som havde til hensigt at understrege den kulturelle selvstændighed og specielle stilling islændingene havde, til trods for mange århundreders stærke religiøse og politiske tilknytning til Norge, senere Danmark. Et af hovedargumenterne var, at på Island talte man et eget sprog, som tidligere var et fælles sprog for alle de nordiske folk, og man havde skrevet litteratur på dette sprog helt fra middelalderen. Mange af de gamle sagaer foregår på Island, $\mathrm{i}$ omgivelser som man havde for øje hele tiden og genkendte, både af navn og beskrivelse. Sagaerne blev derfor knyttet til landet på en speciel måde i folks bevidsthed. I et land, hvor man har meget få synlige arkæologiske minder, og det til trods for en over tusindårig bosættelse, havde de, som boede der før i tiden haft mange store oplevelser som der fandtes fortællinger om. De som boede i landet kunne se på sig selv som efterkommere af de første indbyggere. Island var et "rent» land, uberørt af andre fremmede folk og angreb udenfra. Ifølge gamle kilder, kom der nogle mennesker sejlende til dette uberørte land, satte navn på landskabet og fortalte sagn og myter om det. På denne måde fik landet sjæl og blev bosat af det folk hvis efterkommere fortsat boede der i 1900-tallet. Romantikken fik sagaerne og naturen til at forenes $\mathrm{i}$ en højere enhed, digterne lovpriste landet, naturen og historien, og mange af de bedste digte handler om sagaerne, som havde foregået i denne mægtige natur. At landet både var barsk og på grænsen af det beboelige, blev væk i den romantiske lovpris- ning af flot natur og fredelig fuglesang.

På denne måde blev landet, sproget og historien, sådan som den viste sig i litteraturen, grundlaget for den islandske identitet og det islandske kultursyn. Man lagde stor vægt på alt det som var så specielt for Island: sproget som var så gammelt, naturen som var så fuld af kontraster, og litteraturen som var så enestående. Set $\mathrm{i}$ bakspejlet, så er det disse tre piller som islændingenes identitet bygger på, og der har ikke hersket nogen tvivl om at akkurat dette var kærnen i den islandske kultur. Den store betydning som den xldste tid i Islands historie har fået, har bl.a. ført til at andre dele af den islandske kultur har haft svært ved at markere sig, hvis de ikke kunne knyttes til denne treenighed af sprog, land og folk. Set i dette lys, er det let at forstå den stærke position, litteratur og filologi har indenfor den humanistiske forskning på Island. Håndskrifterne med deres lovtekster, historiske skrifter og sagalitteratur er de vigtigste bærere af den islandske identitet og selvfølelse. De danner grundlaget for hele vor kulturelle eksistens, vort sprog og litteratur. P.g.a. dem har vi status som en kulturnation ude i den store verden. Det har derfor ubevist ført til, at de har højere status som nationale klenodier end de genstande som Nationalmuseet bevarer. Hvis man ikke har tænkt nærmere over dette med identiteten og hvad det er, som har fået stemplet som det "mest islandske", kan man sommetider undre sig lidt over den forskel der er på Det arnamagneanske institut Árnastofnun - der bevarer håndskrifterne og Nationalmuseet, som passer på andre nationale skatte. Museet har selvfølgelig et meget bredere og mere åbent arbejdsfelt, for som allerede sagt, er dets opgave at 
indsamle, registrere, bevare, forske og formidle oplysninger, mens man på Árnatofnun kun har bevaringen, forskningen og formidlingen tilbage. Alligevel har de forskningen til fælles, men på det område hersker der en anden holdning fra samfundet til håndskriftsamlingen end til museet. Árnastofnun defineres som en del af Islands Universitet, selv om instituttet har egen økonomi, og den eneste formelle forbindelse mellem denne institution og universitetet er, at lederen af Árnastofnun er professor ved Islands Universitet med begrænset undervisningspligt. Nationalmuseet, som rent geografisk også er placeret på universitetets område, har ingen akademisk status eller formel forbindelse til Islands Universitet. Rigsantikvaren, som er museets øverste leder, behøver derfor ikke nødvendigvis at have professor kompetence. Det var da også først med museumloven i 1969, at det blev bundet i loven at en af museumspersonalets opgaver skulle være at forske i kulturarven. Universitetet har indtil nu haft tendens til at "glemme» at man har Nationalmuseet som nærmeste nabo, og at der findes ressourcer som det ville være oplagt at bruge. Et lille eksempel, som demonstrerer dette: Selv om man nu i nogle år har haft undervisning i folkloristik/etnologi ved universitetet (et docentur siden 1988), ser det ikke ud til, at det er faldet nogen ind at bruge Nationalmuseets ressourcer, eller at definere, hvor dette studium ville kunne bruges, nemlig på museerne. Tværtimod har undervisningen i folkloristik/etnologi indtil for nylig virket som litteraturinstituttets forlængede arm, hvor man har set på den gamle islandske litteratur fra lidt andre synsvinkler end de traditionelle. Der er ikke taget højde for, at de studenter som studerer folkloristik/etnologi højst sandsynlig vil søge arbejde inden for museumsbranchen og derfor har mere brug for museologi-studium end et litteratur-studium. De har ingen forudsætninger for at blive ordentlige filologer/litteraturforskere, hvis de kun baserer deres studium på folkloristik/etnologi, men burde derimod kunne blive udmærkede traditionsforskere og museumsfolk.

På Nationalmuseet derimod har man ikke kunnet markere sig som den, der burde have mest at sige omkring kulturarven og kulturhistorien. Måske er det fordi man der ikke finder håndskrifter, det specielt islandske, det grundlæggende, men derimod noget som mere tilhører hverdagslivet og ikke er så iøjenfaldende specielt for islændinge. Det kan have sin årsag $\mathrm{i}$ at det ikke er mere end godt 40 år siden at man begyndte at stille spørgsmål ved de ældste historiske kilders kildeværdi, og dermed begyndte at rive sig løs fra filologiens og litteraturens videnskabelige dominans.

På grund af denne holdning kan man ikke diskutere «faglig magt» uden at se på museerne $\mathrm{i}$ en større sammenhæng. Den akademiske diskussion omkring kulturhistoriske spørgsmål ledes ikke af museumsfolk men af universitetet. Der ligger den faglige magt. Blandt de kredse hersker der en bestemt konservatisme, når det gælder udforskningen af Islands ældste samfund. Et eksempel på modstand mod nye dristige meninger er en forskning, som bl.a. bygger på gamle mytologiske symboler og de gamles "world view", hentet fra irske og engelse kilder. At se på Tingvellir og andre kulturområder ud fra arkitektoniske love - et nyt syn - får heller ikke genklang. Nye ideer behøver ikke at være rigtige, eller føre til de rigtige forskningsresul- 
44 tater, men det kan man ikke vide, hvis de ikke får mulighed for at blive fremsat, eller ikke bliver taget alvorlig eller diskuteret.

\section{MUSEERNE OG LITTERATUREN}

De første som ledede Nationalmuseet, var ikke uddannede arkæologer men meget interesserede $\mathrm{i}$ islandsk kulturhistorie og kaldte sig "fornfræðingar» eller oldtidsgranskere. Den første museumslov kom i 1907 og den første rigsantikvar (fra 1908 til 1947) havde studeret nordisk filologi og oldtidskundskab (arkæologi) ved Københavns universitet - uden dog at have afsluttet eksamen. Disse pionerer så ingen grund til at tvivle på de gamle skriftlige kilder, og en av de første arkæologiske registreringer, som blev foretaget i slutningen af 1920-erne, bygger da også i meget høj grad på skriftlige oplysninger. Denne registrering resulterede $i$, at nogle fortidsminder blev fredlyste i 1930 i anledning af Altingets 1000 års jubilæum. Nogle af disse fortidsminder, som man mente var gamle hov eller «skáli», og som blev fredlyste af den grund, har senere vist sig være noget helt andet og mere jordnært som f.eks. et udhus.

Generelt anses det for meget vigtigt og positivt at have gamle historiske kilder. Men det kan også have en modsat virkning. Det kan virke hæmmende på udviklingen inden for den kulturhistoriske forskning, hvis man er for bundet af de ekstisterende, skriftlige oplysninger. Dette kan arkæologer, som bruger andre kilder til deres forskning end de skriftlige, opleve.

Landnámabók og Íslendingabók er de ældste historiske kilder om Islands bebyg- gelse. Landnámabók gør rede for ca. 400 landnamsmænd, hvor de bosatte sig og hvem der var deres efterkommere. Det ældste bevarede håndskrift er fra 1200-tallet, men oplysningerne siges at stamme tilbage helt fra præst Ari den frode (10671148). Ari skrev også Íslendingabók, en sammenfatning af Islands historie fra 870 til 1120, og afsluttede dette arbejde før 1133. Disse gamle skriftlige kilder er enige om, at Island blev bebygget fra Norge, og at de norrøne mennesker, der fandt landet omkring 860 , aldrig havde hørt om landet tidligere. Selv om historikere i de senere år er begyndt at tvivle på den sidste påstand, så er ordets magt stor, og på Island har man altid haft en tendens til at opfatte andre kilder om den ældste bebyggelse, som muligvis peger i retning af noget andet, f.eks. arkæologiske oplysninger, med en stor skepsis. De første landnamsmænd fandt godt nok, i følge skrifterne, nogle levninger fra irske munker, "papar», som var her før, men den bosættelse har ikke været taget højtidelig.

Par sem ekki verơur talið sennilegt, að norrænir menn eða Papar hafi flutt peningana hingað til lands, er ekki eftir nema ein skyring, sú er í upphafi var sennilegust, en hér kemur síðast af virðingu fyrir sögulegum heimildum um fund Íslands og fyrstu byggð par. Sennilegast er, að rómverskir borgarar hafi flutt pessa peninga til Íslands á peim tíma, er peir voru gjaldgengir í rómverska ríkinu. ${ }^{\prime}$

(Eftersom det ikke kan anses for sandsynligt at norrøne folk eller irske munke har transporteret pengene til landet, bliver der kun én forklaring tilbage, den som oprindeligt var den mest sandsynlige, men her diskuteres sidst af respekt for historiske kilder om Islands opdagelse og den første bebyggelse. Det mest sandsynlige er at romerske borgere har bragt 
disse penge til Island på den tid da disse var i brug i det romerske rige. Ovs. R.H.P.).

Dette lille citat fra Kristján Eldjárns doktordisputats er et lysende eksempel på den vægt filologi og norrøn litteratur har i den faglige diskusion omkring Islands ældste historie og definition af kulturarven. Der diskuterer Kristján Eldjárn tre romerske mønter fra slutningen of det 3 . århundrede som blev fundet på Øst-Island tidligt i det 20. årh. Disse romerske mønter passer ikke ind i fortællingen om hvordan Island blev fundet og bebygget. Efter at have diskuteret mulighederne for at de romerske mønter kom til landet med henholdsvis norrøne folk og irske munke, er Kristján Eldjárn kommet frem til det resultat, at det er en højst usandsynlig forklaring, og han kommer med den hypotese at romerske søfarende er kommet til landet på den tid mønterne gjaldt d.v.s. i begyndelsen af det 4. århundrede og har efterladt mønterne. Dette var en dristig påstand i 1950erne, da islandske forskere i nordisk filologi, sagalitteratur og historie havde helt bestemte meninger om betydningen af de ældste skriftlige kilder om Islands historie. Kristján Eldjárn, som var rigsantikvar i 1947-1968 og Islands præsident i 19681980, var en af de første til at sætte spørgsmålstegn ved, hvor historisk korrekte og pålidelige de gamle skrifter er angående opdagelsen og bosættelsen af Island. Eldjárn stod i en stærk faglig position fordi han ikke kun var erfaren som arkæolog, men også som nordisk filolog, så hans ord gjorde indtryk.

En faglig diskussion omkring hvorvidt det er muligt at Island blev opdaget tidligere, og da muligvis også af andre mennesker end de norrøne, er aldrig rigtigt kommet i gang blandt islandske forskere i kulturhistorie. Til det er respekten for den gamle islandske litteratur endnu for stor. Det virker også bekræftende på rigtigheden af de gamle historiske kilder, at de fleste arkæologiske fund stammer fra det 10. og 11. århundrede. Oplysninger om, hvordan Island blev bebygget, foreligger meget tidligt på skrift, og dem har mange ment, at der ingen grund var til at tvivle på. At Ari kan have haft en bestemt grund til at skrive nøjagtigt sådan som han skrev, f. eks. for at begrunde bestemte slækters magt og rigdom, har man ikke fæstet sig særligt meget ved.

\section{AFSLUTNING - MUSEUMSVESENET I DAG}

Denne lille artikel har egentlig mere handlet om museernes magtesløshed end deres magt, i hvert fald når det er tale om faglig magt. Det er måske ikke unaturligt fordi i det lange løb er det den faglige magt, som er den afgørende for museernes status i samfundet. Nationalmuseet er i focus, eftersom det p.g.a. sin position er landets ledende museum. Museet har ikke, indtil nu, magtet at markere sig særlig stærkt som en ledende, akademisk forskningsintitution, selv om nogle ansatte individuelt har skabt sig et navn som habile forskere. Museet har ikke heller endnu forstået at definere sin rolle i samfundsdebatten. Dette hænger selvfølgelig til en stor del sammen med museets manglende økonomiske ressourcer. Den gældende museumslov blev vedtaget i 1989 (l. nr. $88 / 1989)$ med nogle vigtige forandringer og forbedringer i 1994 (1. nr. 98/1994), og det mål og den tidsbegrænsning, som man satte sig dengang, er af økonomiske 
46 årsager langt fra nået. Men mangel på faglig diskussion om Nationalmuseets samfundsrolle, dets reelle status versus den ønskelige, og museets mål, har også haft meget at sige. Men forhåbentligt går vi lysere tider imøde, fordi denne diskussion nu er kommet igang for alvor. For seks år siden startede foreningen af museumsansatte et seminar, som den siden har afholdt årligt. Der formidles der oplysninger omkring aktuelle og faglige problemer indenfor museumsvæsenet. Selv om dette seminar i begyndelsen mest drejede sig om praktiske spørgsmål, bl. a. på grund af meget forskellig faglig kompetence hos deltagerne, så bliver seminarets faglige standard stadig højere. I denne sammenhæng er man begyndt at diskutere museernes rolle for samfundet, hvordan man kan definere deres nytte og hvem der egentlig har brug for museerne.

Det vigtigste er alligevel, at der i det sidste år, på vegne af museumsrådet («Pjóðminjaráð»), er foregået en grundig gennemgang og evaluering af Nationalmuseet og hele det islandske museumvæsen. Resultatet af dette arbejde ventes i de kommende måneder, og det venter alle der interesserer sig for museumsagen, spændte på.

\section{SUMMARY}

Icelandic museums and their position in public culture

Icelandic museums are rooted in the national romantic movement of the 19th century and - as in the other Nordic countries - in the romantic search for a cultural identity. The National Museum was founded in 1863 in a period when the struggle for independence from Denmark culminated. Icelandic nationalism was again challenged in World War 2 which was also coincided with a period of an accelerated modernization. Many people leaving their place of birth for growing urban centres experienced an awakened nostalgic interest in the cultural history of the local places they had left. Another incentive for the creation of local museums to represent a national culture was the presence of Allied troops in the war years. The growth in the number of museums has continued in the post-war period. Three phases are distinguished. In the first phase voluntary enthusiasts are active in bringing together and exhibiting a collection. In the second professional curators appear who do not consider collecting but rather other museum functions as their most important tasks. The museums are normally managed by one person. In the third period professionalization continues, the staff now includes more specialists. In Iceland the antiquarian authority has been vested in Nordic philology, because of the treasure of medieval texts preserved there representing a unique source of knowledge about old Norse history and tradition. Historical truth is considered to be found only in the texts. For this reason the National Museum has had difficulties in gaining recognition when it has defended controversial ideas based on archaeological evidence about the history of the oldest settlement. It is only when archaeological and philological expertise are combined that the role of the museums is accorded respect and their views on the preservation of sites and historic buildings are listened to.

\section{NOTE}

\section{Eldjárn, Kristján. Kuml og haugfé. Akureyri} 1956: 20.

Ragnheiður H. Pórarinsdóttir er Mag.art i folkloristikk, nå seksjonssjef ved Kultur- og undervisningsministeriet bl.a. med museumssporsmål som arbeidsfelt. Adr. Kultur-og undervisningsministeriet, Sölvhólsgata 4, IS-150 Reykjavik. Fax. +354-5623068 